\title{
Preliminary Study and Suggestions on Legal Education in Chinese Universities
}

\author{
Xiaowen Dong \\ Liaoning Police College \\ Dalian, 116036, China
}

\begin{abstract}
This paper analyzed the concept, teaching model and level of legal education in Chinese universities, and then found the basic problems existing, finally put forward causes of them and specific measures for constructing the legal teaching in Chinese universities. It draws the conclusion that the legal teaching level of Chinese universities will be improved by the way of realizing the seamless connection between the legal teaching of Chinese universities and the advanced teaching model of the world.
\end{abstract} reform

Keywords-legal education; educational bias; educational

\section{INTRODUCTION}

Now the focus of Chinese reform is "rule of law", and "ruling the country according to law and building a government under the rule of law" is the future national strategic direction. This decision is both an opportunity and a challenge for the field of legal education. [1] On the one hand, the construction of the rule of law in China requires a large number of legal professionals. From theory to practice, the construction and practice of the rule of law government and the construction of the rule of law are established. This is a rare opportunity for the development and promotion of higher legal education [2]. On the other hand, with the continuous promotion and deepening of the concept of the rule of law, the quality requirements for legal professionals are increasingly strict and comprehensive in the process of legal system track and reform. The University legal education must echo the process of social development and train more excellent law compound talents.

\section{PROBLEMS EXISTING OF LEGAL EDUCATION IN CHINESE UNIVERSITY}

\section{A. Deviations in the concept of legal education in universities}

Nowadays, the legal education of university is far from satisfying the demands of society on the legal profession, and it needs to think and perfect calmly. The foundation of education is the idea. The University legal education should have a correct idea to position it, plan the content of education, and guide the form of education. Unfortunately, the educational concept of law in Chinese universities has deviated. The specific manifestations are:

1) About the orientation of University legal education

There are two main concepts about University legal education: professional education and general knowledge. The former believes that legal education should be aimed at training professional professionals in the legal profession [3]. The latter believes that the purpose of legal education can't be separated from the basic concept of "perfect human education" in universities, and it is necessary to not only cultivate legal professional knowledge[4], but also has a certain level of general knowledge(humanities, social sciences, practice, etc.) of "rational" high-quality talents. The author believes that the above two kinds of positioning theories about University legal education are obviously one-sided and too extreme.

First of all, for the "professional education" of University law, this must be understood as only the training of general legal practitioners. It is believed that legal education can only teach legal knowledge. This leads to two problems: on the one hand, it only teaches simple concepts and superficial legal theories, and on the other hand, it does not have sufficient practice to explain, so that educational theories only stay in books. Imagine that such legal education, apart from fostering a "legal craftsman" who can only rigid memory laws and mechanical application of legal rules, how it can cultivate a legal elite with a deep theoretical foundation, profound legal thinking and rich social experience? Obviously, it is a superficial understanding and regress of legal education to position the University legal education as training "professional education".

Secondly, the theory of "general talents" for University legal education is difficult to achieve. A "full talent" with both legal expertise and comprehensive development of various disciplines is of course what society needs. However, this positioning is too idealistic and basically impossible to achieve. Its defects are mainly in two aspects: First, it is difficult to achieve. "All-talented education" requires the cultivation of high-quality, knowledgeable, moral, and rational talent. This not only requires high quality of students themselves but also makes it difficult to complete the four-year course design. In the actual education, whether it is a collection of extremely high-quality students or the extension of the university semester, the cost of education is huge and difficult to achieve. The second is the lack of professional knowledge of legal education. "Cross the line like a mountain" is particularly obvious in the law profession. Unlike the general social science disciplines, legal education has a strong professional knowledge and practical training, and even has formed a special "legal thinking" in thinking. For example, the ideas of "equivalence of rights and obligations, priority of procedures, and formal justice" can't be understood in general social cognition, but they run through the entire legal education and 
even after practicing. The professional thinking of law makes it necessary to focus on its education. It is difficult to achieve the effect and purpose of legal education by relying on imagination.

\section{2) Contents on University Legal Education}

The content and method of legal education are consistent with its macroscopic orientation. At the present stage, the improper positioning of legal education will naturally lead to various drawbacks in the content of university legal education. Specifically, it is manifested in the following aspects.

a) The offset of the center of gravity of teaching, emphasis on theoretical teaching, lack of training of legal practice ability [5]

Law is a highly practical profession, and it is necessary to inject practical teaching content into the process of education. Only in practice can we integrate knowledge of legal theory and cultivate unique legal thinking in continuous experience. Improve its ability to deal with legal issues [6]. "Theoretical connection with practice" is the ultimate goal for legal education. However, most University legal education is limited to the examination-oriented education of traditional concepts, and due to the restrictions of practical hardware equipment, little attention is paid to the cultivation of legal practice ability. It is only a simple indoctrination of theoretical knowledge and rigid concepts, and the teaching effect is unsatisfactory.

b) The depth of teaching is not enough. It stays on simple theoretical teaching and lacks the cultivation of legal thinking.

Legal education should not only focus on practice, but also be a two-pronged approach to theoretical teaching. Because the practice of law is based on a deep reserve of theoretical knowledge, the purpose of practice is also to cultivate good legal thinking. Legal thinking is a specific way of thinking in the legal profession, and it is the logic of the law in the decision-making process [7]. To think, analyze, solve problems of the thinking mode, or thinking style [8]. It is the core of legal education and the standard to measure the professional level of a law professional. The core competence of lawyers, judges, prosecutors, legal advisers, arbitrators, etc. in the field of legal professions lies in legal thinking. Legal thinking is a legal practitioner when dealing with related legal disputes. Its legal knowledge reserve, legal logic reasoning ability, language expression and finishing ability, legal practice experience, and social comprehensive experience embody, and it is also the core competence of legal practitioners. University legal education does not attach importance to the cultivation of legal thinking, but can only cultivate "legal craftsmen" and it is difficult to cultivate legal elite with core competitiveness.

c) The teaching content is single, and there is a lack of professors and reserves of general knowledge

From the orientation of legal education, it can be seen that on one hand, law is very professional, emphasizing professional thinking and knowledge, but at the same time, the legal profession also needs rich sociological attempts and noble personal sentiments. This is because the legal profession is ultimately to practice in society, to be exposed to various kinds of contradictions and disputes, and to require reserves of various types of comprehensive knowledge. A legal person who only knows the law can't handle legal practice. Plato said that "law is the crystallization of all human wisdom and intelligence, including all social thoughts and morality." It is the best expression of the legal person's ability. However, at this stage of legal education, this point is ignored. There is only a single law course in the curriculum, and there are no courses related to law, philosophy, economics, psychology, forensic science, sociology, and management. This is related to the legal profession. The requirements are seriously out of touch.

\section{B. The deviation of the teaching mode of University legal education}

Due to the deviation in the understanding of the education concept of legal education in universities, there are deficiencies in the orientation of legal education and the planning of teaching content, resulting in the defect of the teaching model of Chinese legal education, and it is difficult to meet the social standards for the legal profession. With can't realize the goal and ideal of legal education. Specifically, there are the following issues:

1) From the perspective of macroscopic teaching mode, legal education has entered the "simple theoretical teaching mode" misunderstanding.

This includes two meanings, one is that legal education does not attach importance to practice exercise. The legal practice part is arranged in the practice of senior year and a small amount of trial observation. The practice time is short and the educational effect is poor. In the classroom, the teacher only indoctrinated the law and reinforced the theoretical concepts. The second is that the theoretical depth of legal education is shallow. Today, when the examination of law is popular, University legal education has also become impatient and utilitarian, paying too much attention to judicial examinations, leading to the weakening of the ratio of theoretical analysis and logical deduction, and instead of paying attention to recitation and memory. Students can only accept it mechanically.

2) From the perspective of microscopic teaching methods, legal education has a tendency to develop into exam-oriented education

The current legal teaching methods are mainly in the form of classroom PPT, quiz, question, roll call, and final examination. Among them, the PPT of teaching mainly introduces the outline content display of concepts, characteristics, meanings, contents, and procedures. Courtroom tests and questions are some legal questions selected by the lecturer according to the teaching situation, and the inspection and enlightening teaching activities are implemented by the students. The usual method of naming places a large part of the test scores in a flat time, making the test difficult to indirectly reduce. The questions of the final exam are mostly conceptual explanations and simple answers. The emphasis on memory rather than thinking and legal reasoning ability limits and restricts the development of students 'personality. Under this model, the overall teaching quality is at a low level. 
3) From the point of view of the curriculum, ignoring the development of students comprehensive quality

The school emphasizes the study of law courses, ignoring the cultivation of students 'legal professional ethics and professional literacy, some students have low moral qualities and weak legal professional ability. The teaching level of legal education in universities is uneven.

\section{The teaching level of legal education in universities is uneven}

In terms of academic qualifications, most of the practitioners of university legal education are highly educated people who have obtained doctoral degrees and master's degrees at home and abroad. From the perspective of legal experience, there are senior legal workers, old teachers who have taught for many years and new teachers who have just graduated. By analyzing the factors of education and experience, we can draw the conclusion that education and experience are necessarily related to the effect of university legal education. In addition, some schools have opened law majors under the serious shortage of teachers. The teaching in this state has led to students 'weak basic knowledge, poor autonomous learning ability, and can't meet the needs of society; there are some utilitarian factors in students ' attitude towards legal learning.

\section{SUGGESTIONS FOR THE REFORM OF UNIVERSITY LEGAL EDUCATION}

\section{A. The orientation of University legal education should be to cultivate "professional talents"}

Higher education is closely focused on cultivating socialist builders and successors who develop comprehensively in morality, intelligence, physical integrity, and labor, and educating people for the party and talents for the country. In the legal education of our country's universities in recent years, every university has put the goal of training the talents of the complex type. The content of training the talents of the complex type of law includes not only studying the current legal system of our country, but also paying attention to and studying the legal system and legal history of other countries. In other words, there is a professional field in which other talents do not have professional knowledge, can be unique in this profession, glowing. In the employment market, employers are more focused on talents with a professional orientation. This is more in line with the efficiency of modern work in which each functional department in a unit has a clear division of labor; each has its own strengths, and cooperates with each other. Therefore, University legal education should not only pay attention to the training and training of law theory, but also pay attention to the reasoning ability and expression ability of legal issues, accumulate deep theoretical knowledge, cultivate professional thinking, and combine the rich experience accumulated in practice to build legal elite.

\section{B. The teaching model of legal education in universities}

The teaching model of legal education in universities should take "cases" as the core and practice as the carrier of teaching to meet the needs of social development. Practical legal education is to integrate legal provisions and their judicial interpretation and application into a real case environment. The classroom uses the Internet to collect information and conduct simulated "case-type" teaching. After class, a "legal clinic" is set up to allow students to contact the case in person and analyze and handle the case themselves so that the "case" and practice can be used throughout the teaching. Through legal means to analyze problems and use legal acts to solve problems, so that students can master the analysis method of practical knowledge. Under the guidance of teachers, to handle real cases, students will receive more skill training so that they can really "think like lawyers" and enhance their training in such skills as analyzing cases, investigating and obtaining evidence, drafting legal documents, etc. to train and improve students' ability to engage in the legal profession.

\section{The curriculum of legal education in universities and the duration of education in the school year should be reformed}

The legal discipline involves all aspects of society, from birth to death, and is reflected in every link of social development. Therefore, a professional legal person needs to have a wider pool of knowledge. The new students who have just entered the university should carry on the basic education of law. In the basic course of law, they should mobilize their enthusiasm and initiative to study law. In the content of the second year of study, courses should set up law courses related to professional disciplines. These courses are the foundation for the study of some future law majors. In the learning content of the junior and senior year, the curriculum should be a more professional law course. In addition, besides setting up law courses for law students, students should also set up elective courses linked to law courses, such as criminology, psychology, sociology, economics, investigation studies, and forensic science.

\section{The threshold of University law and the teaching staff should be raised}

The college law school should improve the minimum score for law students when enrolling students. In addition to the written test results, it can increase the interview links and achieve "excellent and excellent". In the first and second academic years of university studies, other outstanding students can also be absorbed into law majors; at the same time, colleges and universities are required to strictly regulate the quality of teachers. First of all, a law teacher should have a postgraduate degree or above. Before teaching, he should receive the necessary education knowledge training in order to master the teaching methods and begin to engage in legal education after studying and passing the examination [9]. And secondly, we should improve the teachers' assessment system and encourage teachers to innovate teaching methods. Third, the teaching effect of teachers are rewarded, teachers are encouraged to implement teaching reforms, and play a maximum role in teaching and educating people and create maximum efficiency. 


\section{E. Improving the system of assessing legal education in universities}

The goal of legal education assessment in higher education is mainly to achieve the purpose of teaching. In addition to understanding and mastering the school effect of students on the content of legal teaching, many legal teaching will test students' learning results at a certain stage through examinations. The traditional examination model is too simple, lacks a certain degree of flexibility and integrity, and is not in line with the latest developments and changes in the world trend. The legal education of the university is mainly to publicize various laws for contemporary college students, so as to "use" on the basis of "knowing the law and abiding by the law", so that after graduation, college students will devote themselves to the special construction of socialist rule of law. The reform of the teaching evaluation system will be completed through written or oral tests, including the answer to the basic points of legal knowledge, the flexible use of key legal knowledge, and the in-depth thinking of difficult and hot legal knowledge. Make full use of modern teaching methods in the evaluation, and use the network platform for online and offline discussion; let every student be able to participate in the case analysis, so that every student has a chance to practice. College teachers adopt different evaluation methods according to the different characteristics of different subjects in different academic years.

Under the new circumstances, the reform of legal education in colleges and universities should according to the actual conditions, such as subject attributes and social needs, clearly define the training goals of students, establish and improve the training mechanism for University law majors, and enable students to have the comprehensive qualities that legal practitioners should have. Cultivate the knowledge structure that students must engage in the legal profession.

\section{SUMMARY}

In the trend of education and teaching reform and smooth historical development, University legal education must determine the goal of talent training according to the development of the state and society, so that legal education fully reflects the basic teaching model of "teaching-learningpractice-use". To improve the form and content of teaching evaluation in a high level of teachers, college students the comprehensive quality that legal practitioners should build and the teacher should cultivate the knowledge structure that students must engage in legal careers.

\section{REFERENCES}

[1] Yu Jun. Opportunities and Challenges for Legal Education in Contemporary Colleges and Universities. Journal of Inner Mongolia Normal University (Education Science Edition). 2014, vol.10, pp.50. (In Chinese)

[2] Deng Chenxi. Study on the Implementation of Quality Education for Higher Law Profession in Henan Province after Joining WTO. "Journal of Xinxiang Teachers College". 2006, pp.143, (In Chinese)

[3] Wang Jing. Research on the Training Model of High-level Applied Legal Talents: Reform and Development of JM Education in China. Master's thesis of Nanjing University of Technology. 2012, pp.13. (In Chinese)

[4] Zhang Jiazi. University Education from a Humanities Perspective: From Niumandaoheqinsi. Master's thesis at Qufu Normal University. 2012, pp.15. (In Chinese)

[5] Yang Ying. Probe into the Teaching of Higher Vocational Law Specialty from the Perspective of Applied Talent Cultivation. Modern Vocational Education. 2017, pp.12. (In Chinese)

[6] Li Chengchan. The Application of Legal Thinking and Method in Administrative Law Enforcement. "All walks of life." 2018, vol.18, pp.22. (In Chinese)

[7] Zong Huixia. "Study on Judicial Competence of Judges" Doctor's Paper of Nanjing University of Technology. 2013, pp.36. (In Chinese)

[8] Zhao Yuzeng. Interpretation of Legal Methods. Legal Methods. 2006 issue, pp.204. (In Chinese)

[9] Li Yu. Analysis of the Present Situation of Legal Education in Colleges and Universities and Suggestions for Reform. "Legal System and Society." 2008, pp.237. (In Chinese) 